\title{
DETEKSI PERKEMBANGAN LAHAN TERBANGUN KOTA GORONTALO BERDASARKAN CITRA LAST (LANDSAT, ASTER, \& SENTINEL-2A)

\author{
Detection of The Built-up Area Development in Gorontalo City Based on \\ LAST (Landsat, ASTER, \& Sentinel-2A) Imagery.
}

\author{
Arthur Gani Koto ${ }^{1}$, Ivan Taslim² \\ ${ }^{1,2}$ Program Studi Geografi, Universitas Muhammadiyah Gorontalo \\ Email Korespondensi : arthur@umgo.ac.id
}

DOI: http://dx.doi.org/10.31314/jsig.v1i2.177

\begin{abstract}
Built-up area is easily found in urban areas which is the most land use compared to other land use. The development of the built-up area has also increased with increasing population and increasing economic activity. Most of the population activities in the form of economy, services, trade, offices, education, health, and entertainment facilities that are centralized in urban areas have caused the availability of non built-up area to shrink further. Detection of the built-up area can be assessed from remote sensing data using urban indices, multispectral classification (supervised and unsupervised classification), and spectral bands. This study aims to detect the built-up area based on multisensor and multitemporal imagery. Landsat 5 TM, Landsat 8, ASTER, and Sentinel-2B (LAST) images were used in this study. Digital image processing is performed on each image using the guided classification method support vector machine (SVM) algorithm. Four classes of land cover were taken, namely built-up area, vegetation, bare land, and water bodies. Samples of built-up area classes were taken as many as 31 random sampling points spread over the study area. Validation tests were carried out for each image based on the ground check. Results of the study showed that the development of the built-up area was directed to the north and the difference in the extent of information on the built-up area due to differences in spatial resolution.
\end{abstract}

Keywords: built-up area, landsat, aster, sentinel, supervised classification, gorontalo

\begin{abstract}
Abstrak - Lahan terbangun mudah ditemukan di wilayah perkotaan yang merupakan penggunaan lahan paling banyak dibandingkan penggunaan lahan lainnya. Perkembangan lahan terbangun turut meningkat seiring pertambahan jumlah penduduk dan peningkatan aktivitas ekonomi. Sebagian besar aktivitas penduduk berupa ekonomi, jasa, perdagangan, perkantoran, pendidikan, kesehatan, dan sarana hiburan yang terpusat di wilayah perkotaan menyebabkan ketersediaan lahan non-terbangun kian menyusut pula. Deteksi lahan terbangun dapat dikaji dari data penginderaan jauh menggunakan indeks perkotaan (urban index), klasifikasi multispektral (supervised and unsupervised classification), dan saluran spektral (spectral bands). Penelitian ini bertujuan mendeteksi lahan terbangun berdasarkan citra multis-sensor dan multi-temporal. Citra landsat 5 TM, landsat 8, ASTER, dan sentinel-2B (LAST) digunakan dalam penelitian ini. Pengolahan citra digital dilakukan pada masing-masing citra yang menggunakan metode klasifikasi terbimbing algoritma support vector machine (SVM). Sebanyak empat kelas tutupan lahan diambil, yaitu lahan terbangun, vegetasi, lahan terbuka dan tubuh air. Sampel kelas lahan terbangun diambil sebanyak 31 titik secara random sampling yang tersebar di wilayah penelitian. Uji validasi dilakukan untuk masing-masing citra berdasarkan ground check. Hasil penelitian menunjukkan bahwa perkembangan lahan terbangun mengarah ke utara, dan perbedaan luasan informasi lahan terbangun yang disebabkan perbedaan resolusi spasial.
\end{abstract}

Kata kunci: lahan terbangun, landsat, aster, sentinel, klasifikasi terbimbing, gorontalo 


\section{PENDAHULUAN}

Salah satu masalah penting dalam pemetaan wilayah perkotaan adalah menganalisis perubahan penggunaan lahan dari non-pemukiman ke pemukiman (As-syakur et al 2012). Menurunkan informasi lahan terbangun perkotaan dapat menggunakan citra satelit resolusi tinggi (CSRT) maupun citra resolusi spasial menengah. Pada CSRT, metode yang digunakan yaitu interpretasi visual sebab kenampakan objek permukaan bumi sangat detil sehingga mudah diinterpretasi dan delineasi. Berbeda halnya dengan citra satelit resolusi spasial menengah yang kenampakannya tidak begitu detil dan sulit untuk dilakukan interpretasi visual sehingga metode yang digunakan yaitu dengan memanfaatkan panjang gelombang (wavelength) tertentu untuk membangun algoritma. Zhang et al (2014) menyatakan terdapat tiga metode ekstraksi citra penginderaan jauh untuk wilayah terbangun di perkotaan yaitu : berdasarkan indeks spektral, kombinasi data spektral dan informasi spasial, dan menggunakan data multi sensor.

Perencanaan perkotaan membutuhkan waktu dan analisis spasial dan temporal sebagai informasi untuk pengambilan keputusan (Bhaskaran et al 2010). Pemanfaatan teknologi penginderaan jauh yang memanfaatkan citra digital optis resolusi menengah seperti landsat, ASTER, dan Sentinel-2A (LAST) merupakan salah satu data yang dapat diturunkan menjadi informasi mengenai perkembangan lahan terbangun Kota Gorontalo. Meskipun citra LAST tersebut berbeda resolusi spasial, temporal, radiometrik, dan spektral, namun dapat diterapkan untuk kajian perkotaan seperti pada penelitian yang dilakukan Kaimaris \& Patias (2016), Lefebvre et al (2016), Pesaresi et al (2016), Maryati et al (2015), Bhatti \& Tripathi (2014), Assyakur et al (2012), Jieli et al (2010), dan Xu (2008).

\section{METODE DAN DATA}

Penelitian ini dilakukan di Kota Gorontalo. Secara administratif, Kota Gorontalo berbatasan dengan Kab. Bone Bolango dan Kab. Gorontalo sebelah Utara, Kab. Gorontalo sebelah Barat, Kab. Bone Bolango sebelah Timur, dan sebelah selatan Teluk Tomini. Lokasi wilayah penelitian selengkapnya disajikan pada Gambar 1. Kota Gorontalo memiliki 9 kecamatan dengan total luas wilayah 79,03 km2 dan jumlah penduduk 192.031 jiwa. Sebagai ibukota propinsi, Kota Gorontalo merupakan pusat pemerintahan, perdagangan, jasa, ekonomi, dan politik. Beragamnya aktivitas penduduk dan fasilitas yang memadai, menjadikan wilayah ini terdapat kantor pemerintahan, rumah sakit, masjid raya, taman kota, ruang terbuka hijau, stadion, pusat pertokoan, dan pasar besar. Tabel 1 menyajikan jumlah penduduk Kota Gorontalo.

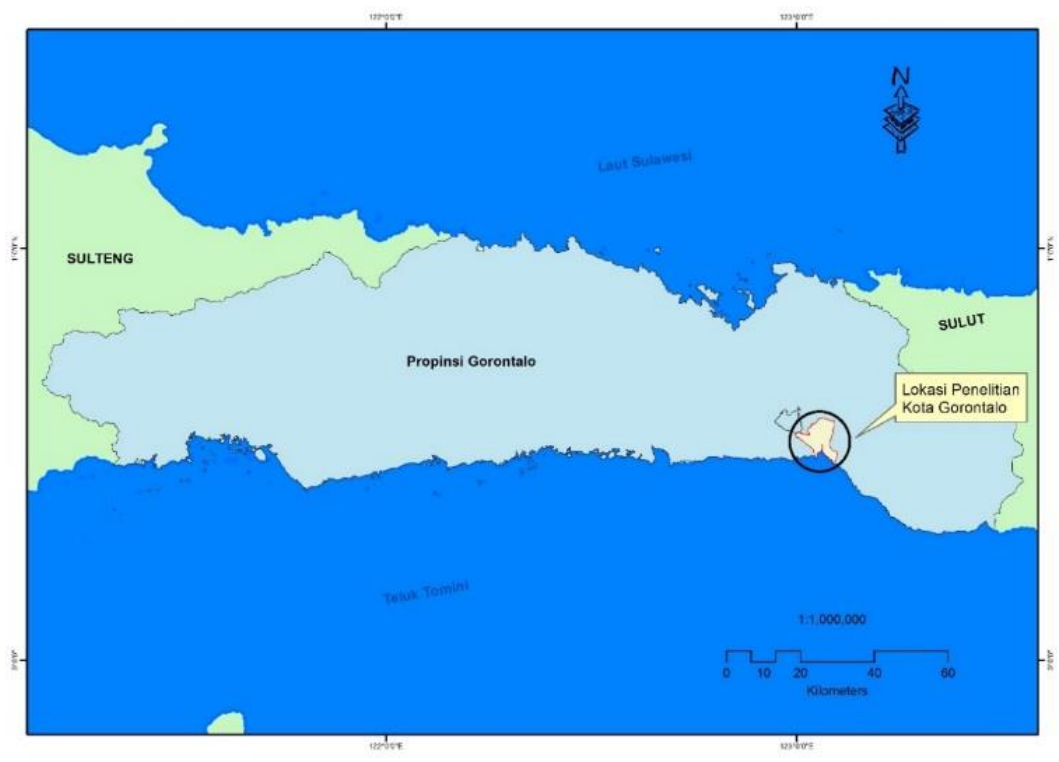

Gambar 1. Lokasi penelitian Kota Gorontalo 
Tabel 1. Jumlah penduduk Kota Gorontalo tahun 2014

\begin{tabular}{clcc} 
No. & \multicolumn{1}{c}{ Kecamatan } & $\begin{array}{c}\text { Luas Wilayah } \\
\left(\mathrm{km}^{2}\right)\end{array}$ & $\begin{array}{c}\text { Jumlah Penduduk } \\
\text { (jiwa) }\end{array}$ \\
\hline 1 & Kota Barat & 28,08 & 22.247 \\
2 & Dungingi & 4,67 & 24.076 \\
3 & Kota Selatan & 2,81 & 22.311 \\
4 & Kota Timur & 5,32 & 26.396 \\
5 & Hulontalangi & 14,23 & 16.508 \\
6 & Dumbo Raya & 14,04 & 18.378 \\
7 & Kota Utara & 8,02 & 17.780 \\
8 & Kota Tengah & 4,81 & 26.698 \\
9 & Sipatana & 5,05 & 17.637 \\
\hline \multicolumn{5}{c}{ Jumlah } & 79,03 & 192.031 \\
\hline Sumber $:$ Kota Gorontalo Dalam Angka & $2016)$
\end{tabular}

(Sumber : Kota Gorontalo Dalam Angka, 2016)

Alat yang digunakan dalam penelitian ini yaitu PC Desktop (AMD FX 8300, RAM 8GB, VGA Card 4 GB ATI Radeon R270). Data yang digunakan yaitu citra Landsat 5 TM perekaman 30 Agustus 1997, Landsat 8 perekaman 13 Februari 2018, ASTER perekaman 3 Maret 2016, citra Sentinel-2B perekaman 18 Maret 2018, DEMNAS (2316-133, 2316-411, 2216-622) peta digital BPS-KEMENTAN (2010), DEMNAS dan observasi lapangan.

Metode penelitian berdasarkan pengolahan citra digital. Citra Landsat, ASTER dan Sentinel-2B. Citra Landsat 8 menggunakan saluran 1-7 yang masing-masing memiliki resolusi spasial $30 \mathrm{~m}$. Saluran citra ASTER yang digunakan yaitu VNIR (1,2,3N). Saluran tersebut memiliki resolusi spasial $15 \mathrm{~m}$. Citra Sentinel-2B menggunakan saluran 2,3,4,5,6,7,8,8A,11,12. Citra LAST kemudian dilakukan proses layer stacking.

Citra LAST telah terkoreksi geometrik sehingga tidak diperlukan koreksi lagi, namun citra tetap diperiksa posisinya menggunakan data DEMNAS wilayah administrasi Kota Gorontalo. Citra LAST kemudian dipotong sesuai dengan wilayah kajian penelitian. Pengambilan region of interest (roi) sampel citra dilakukan pada obyek yang diduga lahan terbangun dan merata pada wilayah kajian. Klasifikasi tak terselia (unsupervised) digunakan sebagai interpretasi awal untuk memperoleh klasifikasi tutupan lahan secara temporary, dan dijadikan peta dasar untuk dibawa ke lapangan. Hasil dari lapangan kemudian di reinterpretasi dan dilakukan klasifikasi terselia (supervised). Klasifikasi terselia menggunakan algoritma support vector machine (SVM).

\section{HASIL DAN PEMBAHASAN}

Citra LAST yang berhasil diunduh dari laman www:earthexplorer.usgs.gov berjumlah 4 scene dimana masing-masing direkam pada tahun 1997, 2016, dan 2018 sebagaimana disajikan pada Tabel 2. Keempat citra tersebut direkam pada musim kemarau dan musim penghujan. Alasan pemilihan waktu perekaman tersebut karena citra kenampakan citra yang minim awan.

Tabel 2. Informasi masing-masing citra yang digunakan

\begin{tabular}{lccc}
\hline \multicolumn{1}{c}{ Sensor } & Date aquired & Bands & Data type \\
\hline Landsat 5 TM & 30 Agustus 1997 & Visible, NIR, SWIR & L1T \\
\hline Landsat 8 & Februari 13, 2018 & $\begin{array}{c}\text { Visible, NIR, SWIR, } \\
\text { Pan, TIR }\end{array}$ & L1TP \\
\hline ASTER & March 3, 2016 & Visible, SWIR & L1T \\
\hline Sentinel-2B & May 18, 2018 & Visible, NIR, SWIR & L1C \\
\hline
\end{tabular}

\section{Pra Pengolahan Citra Landsat 5 TM dan Landsat 8}

Format file citra landsat 5 TM dan landsat 8 dalam bentuk *.TIFF. Landsat 5 TM telah 
terkoreksi geometrik sehingga tidak perlu dilakukan koreksi lagi. Begitupun landsat 8, berdasarkan metadatanya telah terkoreksi geometrik dan radiometrik (Landsat 8 Handbook, 2015) sehingga kedua proses tersebut tidak dilakukan pada penelitian ini. Namun untuk memastikan bila citra telah sesuai posisinya secara geometrik di permukaan bumi, maka dilakukan teknik tumpang susun (overlay) menggunakan peta digital BPS-KEMENTAN administrasi Kota Gorontalo dan DEMNAS (digital elevation model nasional).

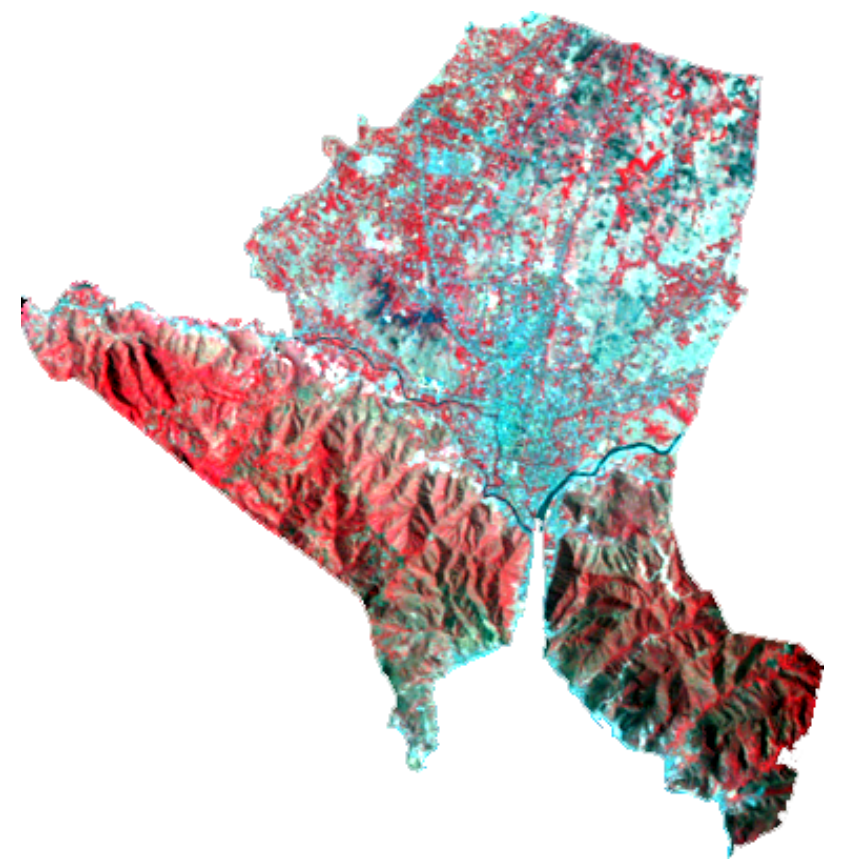

Gambar 2. Citra landsat 5 TM Kota Gorontalo (komposit 432)

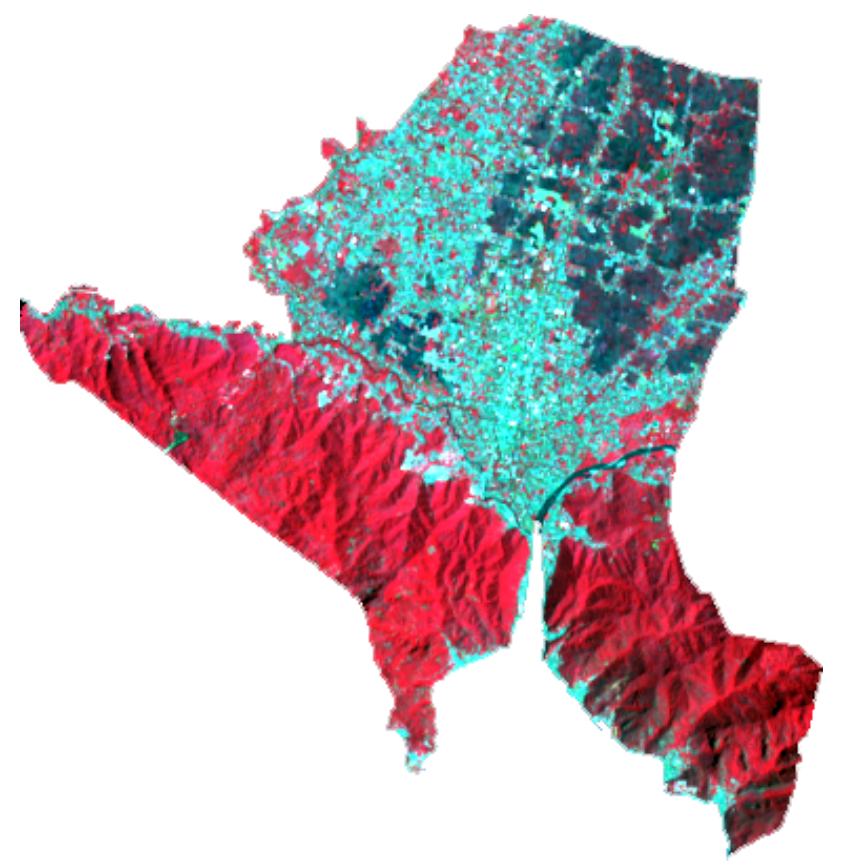

Gambar 3. Citra landsat 8 Kota Gorontalo (komposit 543)

Masing-masing citra kemudian dilakukan proses pemotongan (clipped) menggunakan data spasial administrasi Kota Gorontalo, sehingga hasil akhirnya berupa wilayah administrasi Kota Gorontalo sebagaimana disajikan pada Gambar 2 dan Gambar 3. Setelah pemotongan citra, proses selanjutnya dilakukan penyatuan saluran (layer stacking) yang memiliki resolusi spasial $30 \mathrm{~m}(1,2,3,4,5,6,7)$ untuk landsat 8 dan untuk landsat $5 \mathrm{TM}$ saluran 1,2,3,4,5,7. Tujuan dilakukannya layer stacking ini yaitu untuk memudahkan dalam analisis dan interpretasi citra. 


\section{Pengolahan Citra Landsat 5 TM dan landsat 8}

Kenampakan visual lahan terbangun pada citra landsat 5 TM menggunakan komposit 754, sebagaimana disajikan pada Gambar 4. Untuk kenampakan visual lahan terbangun pada citra landsat 8, maka digunakan komposit 764 (urban composite) seperti nampak pada Gambar 5. Citra kemudian dilakukan proses penajaman kontras agar perbedaan antar objek permukaan bumi nampak jelas dan tajam secara visual, sehingga mudah untuk diinterpretasi.

Komposit 764 tersebut dapat membedakan dengan jelas lahan terbangun dengan nonterbangun, seperti sawah yang sedang diairi, dan vegetasi. Komposit 764 tersebut memiliki pantulan tinggi pada panjang gelombang SWIR.

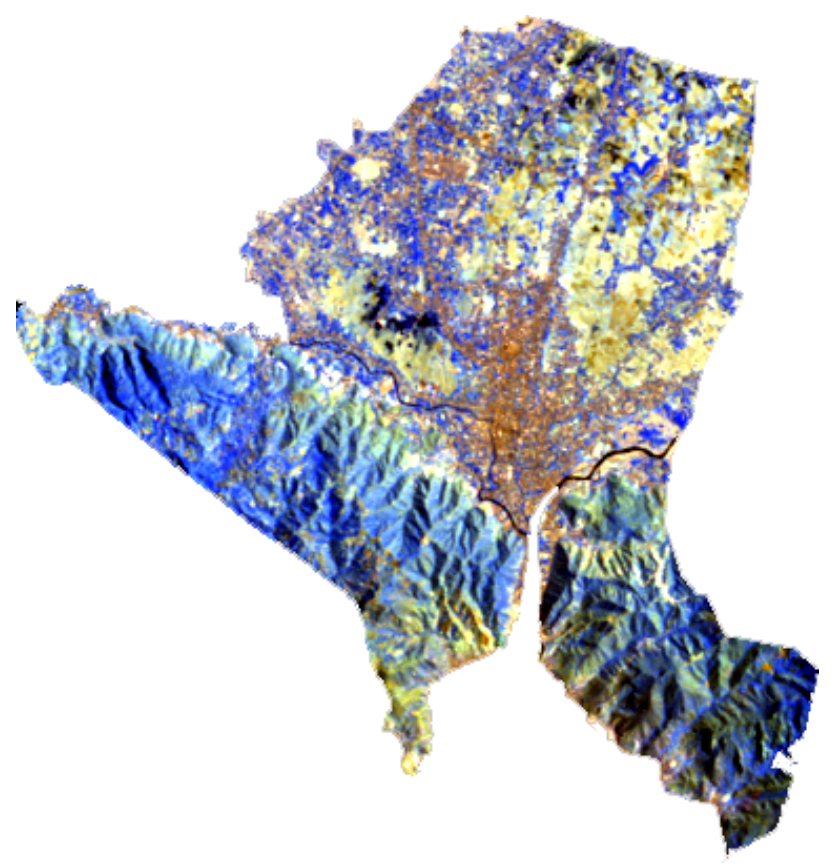

Gambar 4. Citra landsat 5 TM Kota Gorontalo (komposit 754)

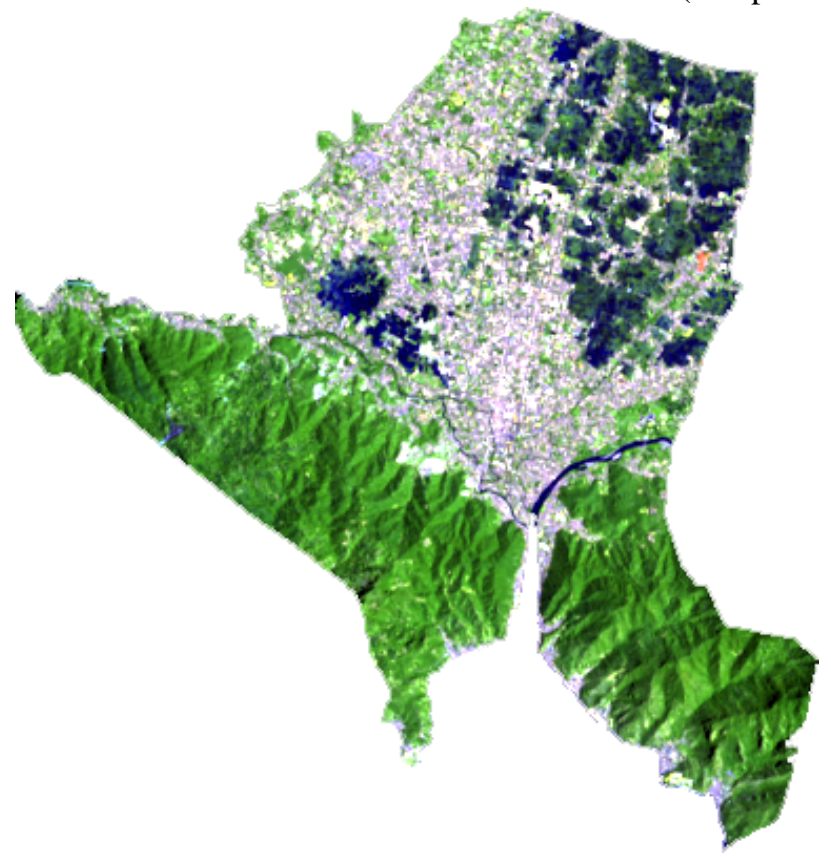

Gambar 5. Citra landsat 8 Kota Gorontalo (komposit 764)

Klasifikasi tutupan lahan citra landsat 5 TM terdiri atas 4 kelas yaitu lahan terbangun, vegetasi, lahan terbuka dan tubuh air, selengkapnya disajikan pada Tabel 3. Peta tutupan lahan Kota Gorontalo dari citra landsat 5 TM disajikan pada Gambar 6. Klasifikasi tutupan lahan Kota 
Gorontalo dari citra landsat 8 disajikan pada Tabel 4 dan peta tutupan lahan pada Gambar 7 .

Tabel 3. Luas wilayah masing-masing kelas tutupan lahan Kota Gorontalo dari citra landsat 5 TM tahun 1997

\begin{tabular}{|c|c|c|}
\hline Tutupan lahan & Luas (ha) & Persentase (\%) \\
\hline Lahan terbangun & $1.669,12$ & 25,70 \\
\hline Tubuh air & $2.127,05$ & 32,75 \\
\hline Vegetasi & 186,65 & 2,87 \\
\hline Lahan terbuka & $2.512,03$ & 38,68 \\
\hline Jumlah & $6.494,85$ & 100 \\
\hline
\end{tabular}

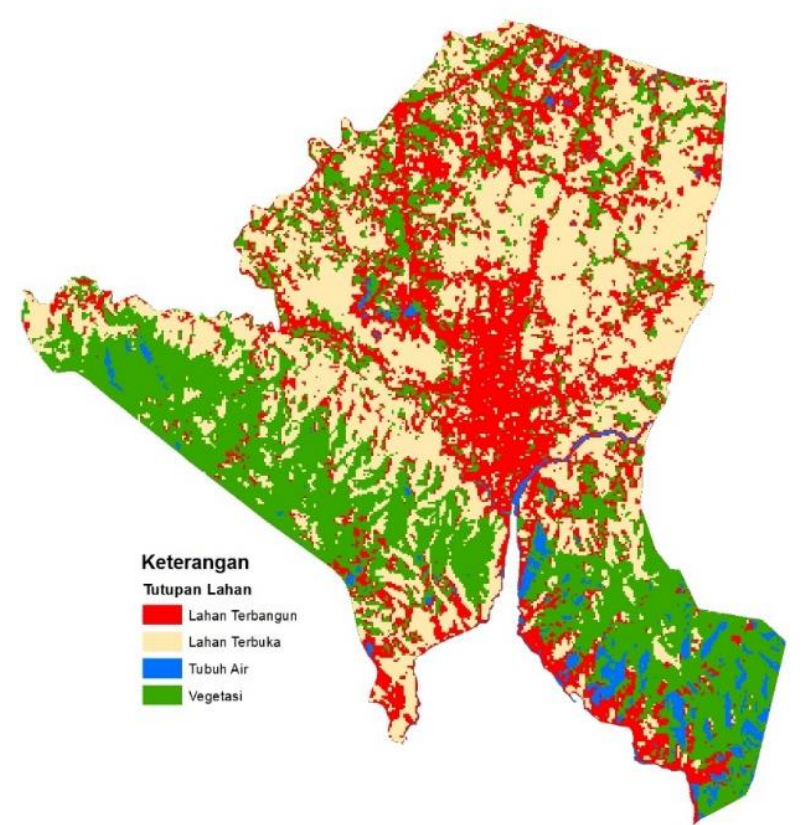

Gambar 6. Tutupan lahan Kota Gorontalo dari citra landsat 5 TM tahun 1997

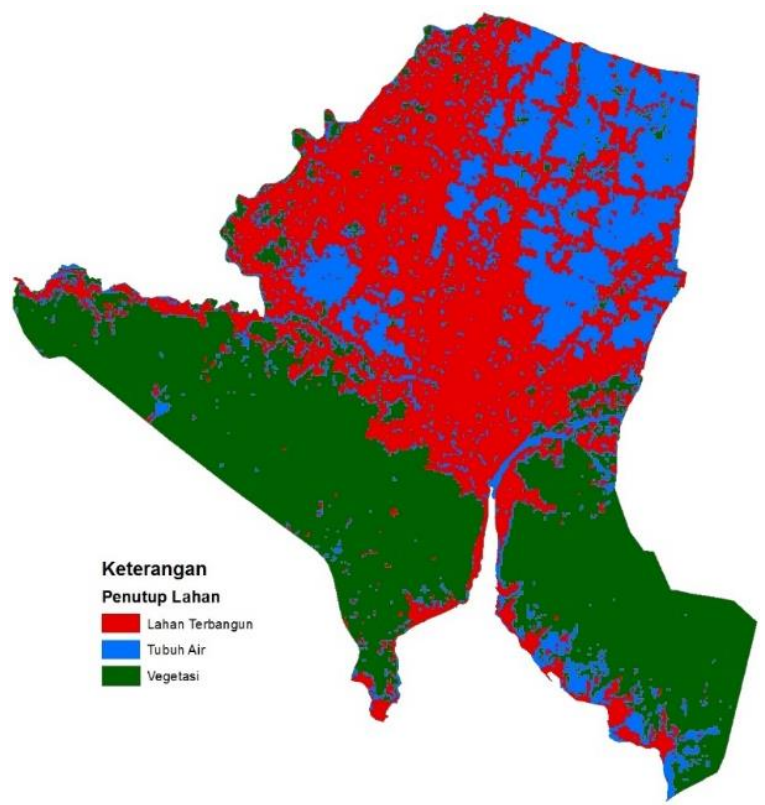

Gambar 7. Tutupan lahan Kota Gorontalo dari citra landsat 8 tahun 2018 
Tabel 4. Luas wilayah masing-masing kelas tutupan lahan Kota Gorontalo dari citra landsat 8 tahun 2018

\begin{tabular}{|c|c|c|}
\hline Tutupan lahan & Luas (ha) & Persentase (\%) \\
\hline Lahan terbangun & $2.426,31$ & 37,4 \\
\hline Tubuh air & $1.406,45$ & 21,6 \\
\hline Vegetasi & $2.662,26$ & 41,0 \\
\hline Jumlah & $6.495,02$ & 100 \\
\hline
\end{tabular}

\section{Pra Pengolahan Citra ASTER}

Citra ASTER yang diunduh terdiri atas saluran visible near infrared (VNIR) dan thermal infrared (TIR). Saluran VNIR dengan resolusi spasial 15m mencakup saluran hijau, merah dan near infrared. Saluran TIR dengan resolusi spasial 90m terdiri atas saluran 10,11,12,13, dan 14. Citra ASTER ini merupakan level L1T dimana telah terkoreksi geometrik dan radiometrik (ASTER L1T Product user's Guide, 2015). Citra ASTER kemudian dilakukan proses layer stacking untuk saluran VNIR yang memiliki resolusi spasial $15 \mathrm{~m}$.

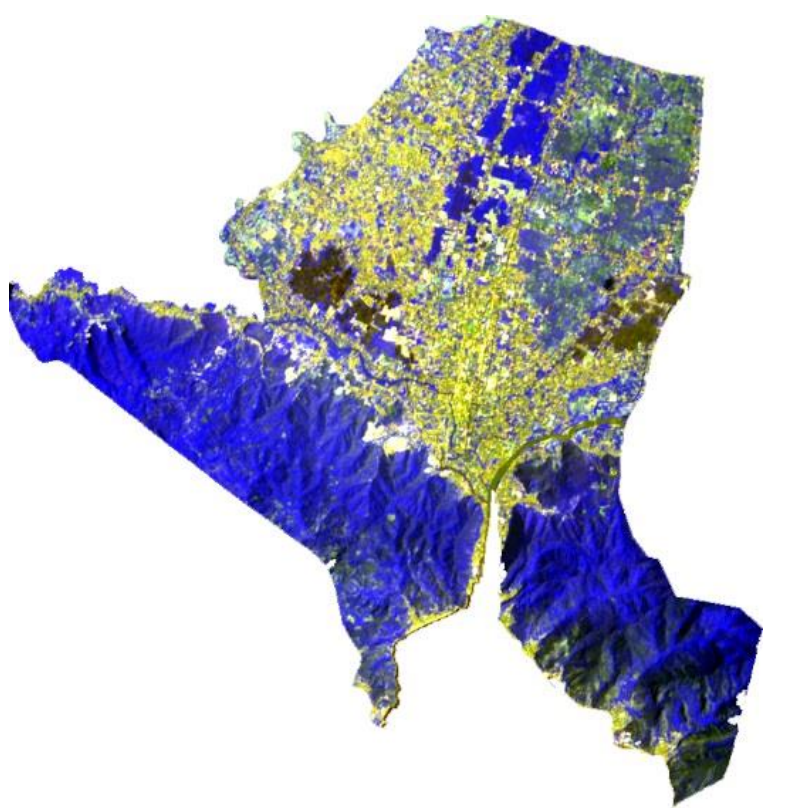

Gambar 8. Citra ASTER Kota Gorontalo tahun 2016 (komposit 123)

\section{Pengolahan Citra ASTER}

Komposit 321 digunakan untuk melakukan klasifikasi citra. Kelas tutupan lahan dibagi menjadi empat kelas yaitu lahan terbangun, vegetasi, tubuh air dan lahan terbuka. Berbeda dengan citra landsat 8, citra ASTER pada saat perekaman memasuki peralihan musim panen ke musim tanam padi. Sawah yang diairi nampak sebagai tanah air dangkal dan sawah yang setelah panen nampak sebagai lahan terbuka. 


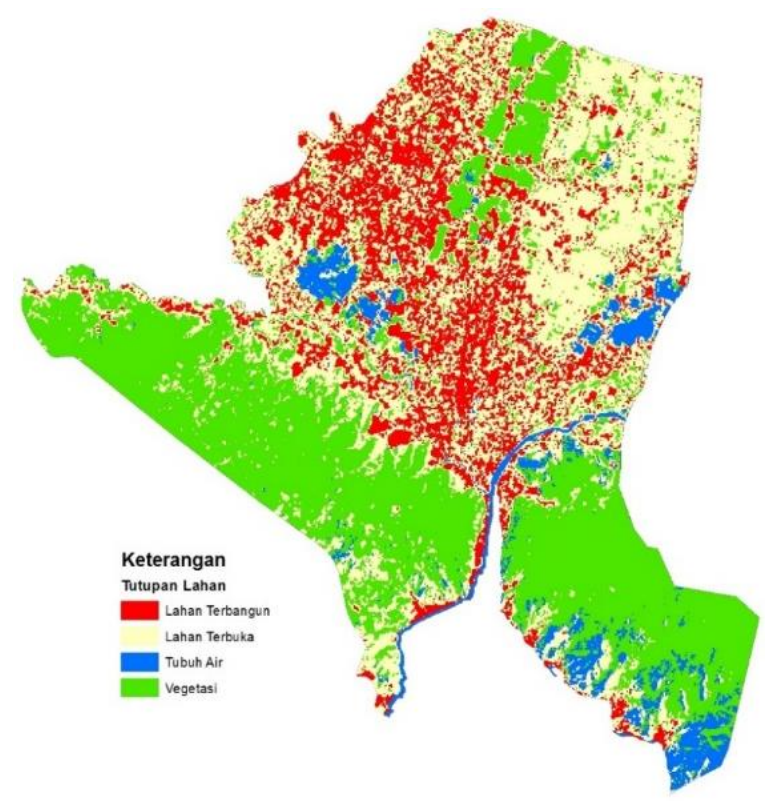

Gambar 9. Tutupan lahan Kota Gorontalo dari citra ASTER tahun 2016

Tabel 5. Luas wilayah masing-masing kelas tutupan lahan Kota Gorontalo dari citra ASTER tahun 2016

\begin{tabular}{|c|c|c|}
\hline Tutupan lahan & Luas (ha) & Persentase (\%) \\
\hline Lahan terbangun & $1.173,96$ & 18,1 \\
\hline Tubuh air & 376,58 & 5,8 \\
\hline Vegetasi & $2.492,90$ & 38,4 \\
\hline Lahan terbuka & $2.451,56$ & 37,7 \\
\hline Jumlah & $6.495,00$ & 100 \\
\hline
\end{tabular}

\section{Pra Prosesing Citra Sentinel-2B}

Citra sentinel telah terkoreksi radiometrik, geometrik, orthorektifikasi dan registrasi spasial (Sentinel L1T Handbook, 2015). Terdiri atas 13 saluran dengan resolusi spasial $10 \mathrm{~m}$ $(2,3,4,8), 20 \mathrm{~m}(5,6,7,8 \mathrm{~A}, 11,12), 60 \mathrm{~m}(1,9,10)$. Saluran yang digunakan dalam penelitian ini adalah $2,3,4,5,6,7,8,8 \mathrm{~A}, 11,12$.

Administrasi Kota Gorontalo dari citra sentinel-2B termasuk dalam dua path yaitu N0206_R060_T51NVA dan N0206_R060_T51NWA. Format file citra sentinel yaitu *.jp2. Format file ini kemudian di konversi menjadi *.tiff agar sistem proyeksinya sama dengan citra landsat 8 dan ASTER yaitu geografis. Proses konversi tersebut menggunakan bantuan perangkat lunak Quantum GIS memanfaatkan tools yang dikembangkan oleh Luca Congedo (2013) yaitu semi automatic classification (SCP).

Proses layer stacking dan konversi tersebut dilakukan dengan menggabungkan saluran yang memiliki resolusi spasial $10 \mathrm{~m}$ dan $20 \mathrm{~m}$ yang hasil akhirnya berupa citra beresolusi spasial $10 \mathrm{~m}$. Selanjutnya dilakukan proses penggabungan dua wilayah (mosaicking) berdasarkan georeferensinya. Kenampakan administrasi Kota Gorontalo yang telah mengalami proses diatas sebagaimana pada Gambar 10. 


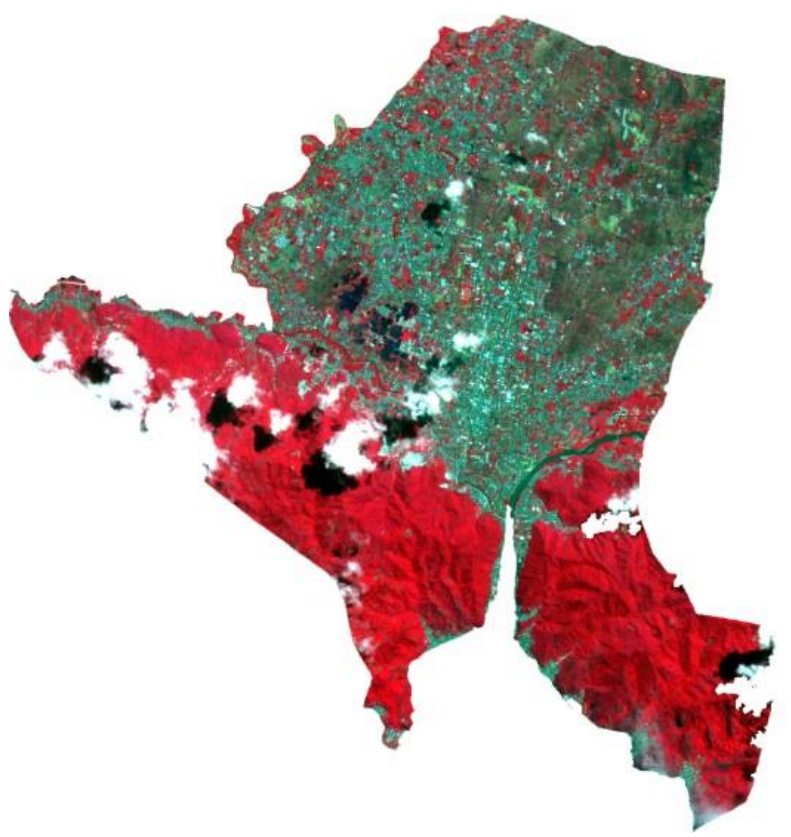

Gambar 10. Citra sentinel-2B Kota Gorontalo (komposit 843)

\section{Pengolahan Citra Sentinel-2B}

Klasifikasi citra menggunakan komposit 12,11,4. Komposit ini merupakan warna semu (false color urban) untuk wilayah kota. Klasifikasi tutupan lahan dibagi 6 kelas yaitu lahan terbangun, vegetasi, tubuh air, awan, bayangan awan, dan lahan terbuka. Peta tutupan lahan Kota Gorontalo disajikan pada Gambar 11.

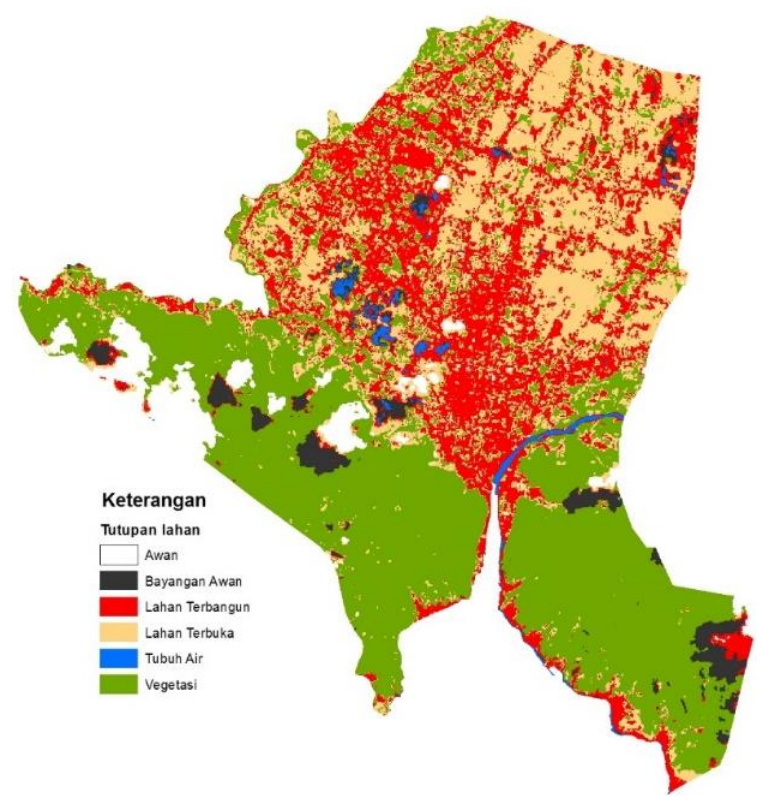

Gambar 11. Tutupan lahan Kota Gorontalo citra sentinel-2B 
Tabel 6. Luas wilayah masing-masing kelas tutupan lahan Kota Gorontalo dari citra Sentinel-2B tahun 2018

\begin{tabular}{|c|c|c|}
\hline Tutupan lahan & Luas (ha) & Persentase $(\%)$ \\
\hline Lahan terbangun & $1.551,50$ & 23,89 \\
\hline Tubuh air & 58,92 & 0,91 \\
\hline Vegetasi & $2.680,86$ & 41,28 \\
\hline Lahan terbuka & $1.735,12$ & 26,71 \\
\hline Awan & 266,93 & 4,11 \\
\hline Bayangan awan & 201,69 & 3,11 \\
\hline Jumlah & $6.495,00$ & 100 \\
\hline
\end{tabular}

\section{Pengambilan titik sampel}

Pengambilan titik sampel lokasi lahan terbangun berdasarkan interpretasi visual citra sentinel-2B. Hal tersebut dilakukan karena citra sentinel-2B lebih jelas kenampakannya secara visual karena mempunyai resolusi spasial yang lebih tinggi dibanding landsat $5 \mathrm{TM}$, landsat 8 dan ASTER. Titik sampel diambil secara random sampling sebanyak 31 titik koordinat di wilayah yang diperkirakan lahan terbangun dan menyebar seluruh wilayah penelitian. Lokasi sebaran titik sampel disajikan pada Gambar 12.

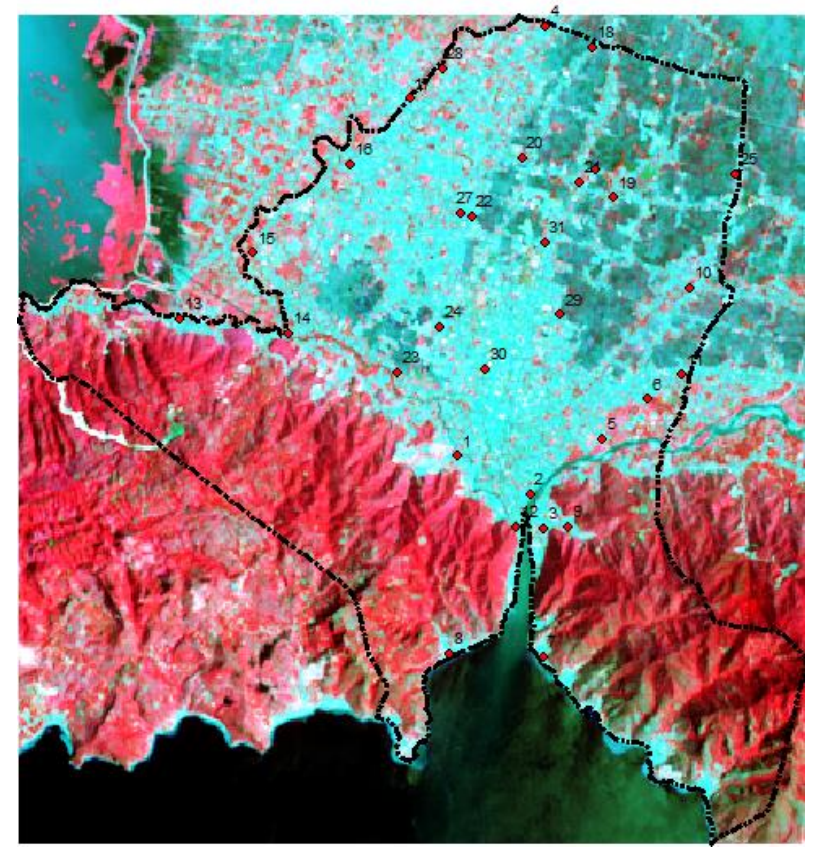

Gambar 12. Sebaran lokasi titik sampel

\section{Lahan Terbangun Kota Gorontalo}

Perkembangan lahan terbangun di Kota Gorontalo tiap tahun semakin meningkat. Luas lahan terbangun Kota Gorontalo berdasarkan analisis citra landsat 5 TM Tahun 1997 adalah 1.669,12 ha dan citra landsat 8 Tahun 2018 sebesar 2.426,31 ha. Luas lahan terbangun tersebut, terjadi peningkatan dibandingkan pada Tahun 2013, dimana Maryati et al (2015) menuliskan bahwa berdasarkan analisis citra landsat Tahun 2013, luas lahan terbangun Kota Gorontalo sebesar 2.213 ha.

Gambaran lahan terbangun Kota Gorontalo menunjukkan terjadinya perkembangan yang kenampakannya secara visual berkembang ke arah utara. Berdasarkan survei lapangan, lahan terbangun menempati penggunaan lahan semak belukar dan lahan padi sawah irigasi. Dari hasil analisis citra, secara visual nampak lahan terbuka diidentifikasi sebagai lahan terbangun. Hal ini terjadi karena tercampurnya piksel lahan terbangun dengan lahan terbuka ketika proses pengambilan sampel untuk pengkelasan tutupan lahan yang menggunakan klasifikasi terbimbing (supervised). Kondisi tersebut karena nilai spektral lahan terbangun dan lahan terbuka tidak berbeda jauh sehingga nilai piksel keduanya tercampur. 


\section{KESIMPULAN}

Perkembangan lahan terbangun di Kota Gorontalo yang mengarah ke bagian utara wilayah kota. Wilayah lahan terbangun tersebut berkembang menempati lahan-lahan kosong, sawah dan semak belukar. Dalam menurunkan informasi lahan terbangun dari citra LAST terjadi perbedaan luasan. Hal ini terkait dari perbedaan resolusi spasial, waktu perekaman dan panjang gelombang tiap saluran citra.

\section{UCAPAN TERIMAKASIH}

Penulis mengucapkan terimakasih kepada DRPM RISTEKDIKTI yang telah membiayai sepenuhnya penelitian ini. Penulis juga mengucapkan terimakasih kepada United States Geological Survey (USGS) yang telah diizinkan mengunduh secara gratis citra Landsat, ASTER, dan Sentinel-2B melalui laman www.earthexplorer.usgs.gov.

\section{DAFTAR PUSTAKA}

As-syakur, A. R., Adnyana, I. W., Arthana, I. W., \& Nuarsa, I., 2012. Enhanced Built-Up and Bareness Index (EBBI) for Mapping Built-Up and Bare Land in an Urban Area. Remote Sensing, 4, 2957-2970.

Bhaskaran, S., Paramananda, S., \& Ramnarayan, M., 2010. Per-pixel and object-oriented classification methods for mapping urban features using Ikonos satellite data. Applied Geography, 30, 650-665.

Bhatti, S. S., \& Tripathi, N. K., 2014. Built-up area extraction using Landsat 8 OLI imagery. GIScience \& Remote Sensing, 4, 445-467.

Chen, Y., Shi, P., Fung, T., Wang, J., \& Li, X., 2007. Object-oriented classification for urban land cover mapping with ASTER imagery. International Journal of Remote Sensing, 28(20), 4645-4651.

Congedo, L., 2013. Semi-Automatic Classification Plugin for QGIS. [pdf] Rome: Sapienza University. Available at:<http://www.planning4adaptation.eu/>

Congedo, L., Munafo', M., \& Macchi, S., 2013. Investigating the Relationship between Land Cover and Vulnerability to Climate Change in Dar es Salaam. Rome: Sapienza University. Retrieved from http://www.planning4adaptation.eu/Docs/papers/08_NWPDoM_for_LCC_in_Dar_using_Landsat_Imagery.pdf.

Daldjoeni, N., 2014. Geografi Kota dan desa. Yogyakarta: Penerbit Ombak.

Jieli, C., Manchun, L., Chenglei, S., \& Wei, H., 2010. Extract Residential Areas Automatically by New Built up Index. Theme Paper for the 18th International Conference on Geoinformatics (pp. 1-5). IEEE.

Kaimaris, D., \& Patias, P., 2016. Identification and area measurement of the built-up area with the built-up index (BUI). International journal of advanced remote sensing and GIS, 5(6), 1844-1858.

Kota Gorontalo Dalam Angka., 2016. Gorontalo: Badan Pusat Statistik Kota Gorontalo.

Koto, A. G. (2013). Pemanfaatan Teknologi Penginderaan Jauh dan SIG Untuk Evaluasi Lahan Kering di Kabupaten Bantaeng, Sulawesi Selatan. Universitas Gadjah Mada, Fakultas Geografi. Yogyakarta: Universitas Gadjah Mada.

Landsat 7 Users Handbook. (n.d.).

Landsat 8 Users Handbook, Versi 1.0., 2015. U.S. Geological Survey.

Lefebvre, A., Sannier, C., \& Corpetti, T., 2016. Monitoring Urban Areas with Sentinel-2A Data Application to the Update of the Copernicus High Resolution Layer Imperviousness Degree. Remote Sensing, 8, 606-626.

Maryati, S., Sune, N., \& Sutarno., 2015. Analisis spasial arah perkembangan Kota Gorontalo menggunakan citra landsat multitemporal. Simposium Nasional Sains Geoinformasi IV, 442-445.

Pesaresi, M., Corbane, C., Julea , A., Florczyk , A. J., Syrris, V., \& Soille, P., 2016. Assessment of the Added-Value of Sentinel-2 for Detecting Built-up Areas. Remote Sensing, 8, 299316.

SENTINEL-2 Users Handbook., 2015. 
Xu, H., Huang, S., \& Zhang, T., 2013. Built-up land mapping capabilities of the ASTER and Landsat ETM+ sensors in coastal areas of southeastern China. Advances in Space Research, 52, 1437-1449.

Zhang, J., Li, P., Wang, J., 2014. Urban Built-Up Area Extraction from Landsat TM/ETM+ Images Using Spectral Information and Multivariate Texture. Remote Sensing, 6, 73397359 . 